
\title{
25 Research Soure \\ First comes love...then comes taxes? A look at how tax law influences the decision to get married
}

\section{Francesca Barigozzi}

Helmuth Cremer

Kerstin Roeder

\section{Video Abstract}

Keywords: tax penalty, tax bonus, taxes, marriage, incentive, proposal, motive, marriage penalty, marriage bonus, proposal game, signaling, love, liability, pooling equilibrium, probability, separating equilibrium, information transmission, University of Augsburg, University of Toulouse Capitole, University of Bologna

Posted Date: September 20th, 2019

DOI: https://doi.org/10.21203/rs.2.15059/v1

License: (c) (i) This work is licensed under a Creative Commons Attribution 4.0 International License.

Read Full License 


\section{Abstract}

Can your country's tax laws help you find true love? A research team based in Europe has found that a government's tax scheme surrounding marriage could affect a couple's decision to tie the knot. The majority of countries across the globe have a tax code that changes according to marital status - usually in the form of either a tax penalty or tax bonus. With a penalty, a couple will end up paying more in taxes than two similarly compensated single individuals, and with a bonus, they will pay less. To get to the heart of whether the financial implications connected to such tax laws influence a couple's desire to get married, the researchers applied a rigorous theoretical model they called the marriage proposal game. In the game, two potential spouses - Sam and Robin - can either get married, live together without formal marriage, or break up. The researchers examined the couple's fate under two different scenarios: whether their marriage would boost their earnings thanks to a tax bonus or, conversely, whether wedded bliss would come at the cost of a tax penalty. Surprisingly, they found that a tax bonus could actually lower the odds that the couple will get married, while a tax penalty may increase the likelihood that they wed. Just why would the chance to bring in some extra cash potentially lead to an "I don't"? The answer may come down to the issue of motive. If Sam stands to financially benefit from a marriage proposal, can Robin really be sure that Sam's reasons for asking are pure? Similarly, the desire to get married despite a financial loss may signal that Sam's asking comes only from a place of true love. The model's predictions help reveal the potential effects that a tax system can have on the marriage decision, which could have important implications for how tax policy is designed and how easy it is to say "yes". The striking result is that a marriage bonus may actually reduce the chances that Sam and Robin get married. 